\title{
Molecular Relaxations of Aromatic Polymers
}

by

\author{
Hirotaro Kambe, Masakatsu Kochi, Teiji Kato, \\ Shigenori KugA and Masashige Murakami \\ (Institute of Space and Aeronautical Science, University of Tokyo, Tokyo)
}

The dynamic mechanical and dielectric relaxations of an aromatic polyimide film, du Pont Kapton H, were measured. Mechanical dispersions at $1 \mathrm{~Hz}$ were found at $190^{\circ} \mathrm{K}(\beta), 370^{\circ} \mathrm{K}\left(\beta^{\prime}\right)$, $520^{\circ} \mathrm{K}\left(\beta^{\prime \prime}\right)$, and $670^{\circ} \mathrm{K}(\alpha)$. The lowest temperature dispersion $\beta$ was assigned to a "water" dispersion. The mechanical dispersions above $370^{\circ} \mathrm{K}$ were discussed in reference to data given by Gillham and by Wrasidlo. By dielectric measurements we found distinct $\beta^{\prime}$ and $\beta^{\prime \prime}$ dispersions. Wrasidlo also found $\beta^{\prime}$, and $\beta^{\prime \prime}$ peaks in the dielectric loss curves but not a $\beta$ loss; for the $\beta$ loss we found a very small absorption peak. In the DSG curves, there were no marked transitions. In the case of the thermal shrinkage behavior of stretched polyimide films, as analyzed by thermomechanical analysis, we found three separate processes corresponding to mechanical loss peaks. The respective activation energies for the processes are $\beta^{\prime} 10 \mathrm{kcal} / \mathrm{mol}, \beta^{\prime \prime} 25 \mathrm{kcal} / \mathrm{mol}$, and $\alpha 33 \mathrm{kcal} / \mathrm{mol}$, which are consistent with values determined by Wrasidlo in his dielectric measurements. The molecular mechanisms of these three relaxations are discussed.

\section{芳香族高分子の分子緩 和}

\author{
神戸博太郎・古知政勝・加藤貞二・空閑重則・村上雅茂*
}

（原稿受理：1974年1月 5 日）

1 序

主鎖に芳香環またはへテロ環を含む高分子は，軟化温度が高く， 優れた耐熱性を示す．乙の種の高分子の粘弾性は, 主鎖の剛直な 分子構造と関連して興味深い. 一方てれらの芳香族高分子は, 室 温以下の低温においても，かなり強靶であるととが知られている。 ガラス転移温度が高く, 観測にかからないととが多いが, ガラス 状態で泠間延伸ができるので, ガラス状態にいくつかの分子緩和 機構が存在するものと考学られる.

われわれは芳香族高分子の典型として次の構造をもつポリピロ メリットイミド, du Pont Kapton H フィルムを選で, その力 学および誘電緩和を調べてきた ${ }^{1 \sim 3)}$.<smiles>CCCCCC(C)(C)C</smiles>

\footnotetext{
* 東京大学宇宙航空研究所 東京都目黒区駒場 4-6-1
}

最近ての高分子に関して発表されたいくつかの測定結果と併せ て, 分子構造と緩和機構との関係を検討した結果を述べる.

\section{2 実験結果と討論}

$2 \cdot 1 \beta$ 分 散 われわれの得た結果をまとめて Fig. 1 亿示す．低温での $\beta$ 分

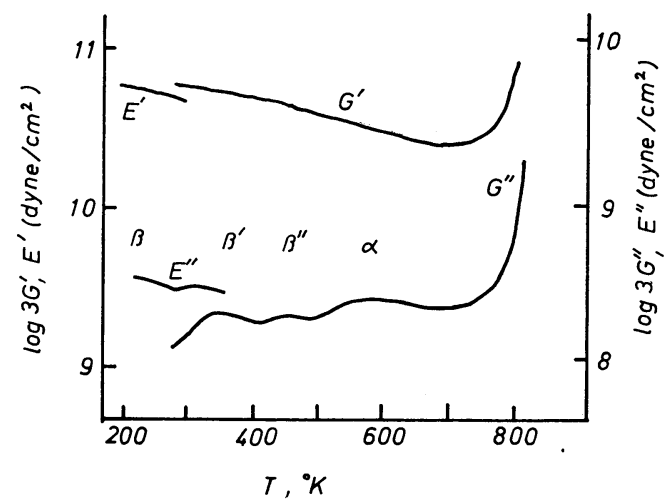

Fig. 1. Dynamic mechanical properties of polypyromellitimide film. [E: $10 \mathrm{~Hz}, 3 G: 0.1 \mathrm{~Hz}]$ 
散 $\left[190^{\circ} \mathrm{K}, 1 \mathrm{~Hz}\right]$ は, 水の吸収によって強められ, 乾燥すると消 失する水分散で, 誘電測定によっても観察できる。乙の吸収は最 近 $\operatorname{Lim} ら^{4)}$ によって確められた。 無定形のPI は結晶分散を示 さず，また回転しうる側基もないので，100ํK 以下の極低温では 分散を示さない5).

\section{$2 \cdot 2$ 高温分散}

室温より上に少なくとも三つの分散 $\beta^{\prime}, \beta^{\prime \prime}, \alpha\left[370,520,670^{\circ} \mathrm{K}\right.$, $1 \mathrm{~Hz}$ がみられる ${ }^{122)}$. Gillham-Roller ${ }^{6)}$ および Wrasidlo ${ }^{7)}$ もと れら三つの分散を記録している. $820^{\circ} \mathrm{K}$ 以上で熱劣化により橋か けを生じ，弾性損失率が急に大きくなる，熱重量測定 (TG) に よって，乙の温度域から重量減少がみられる，同じ温度領域での 誘電測定の結果を Fig. 2 亿示す。 $\beta^{\prime}, \beta^{\prime \prime}$ は現われるが, $\beta$ はで

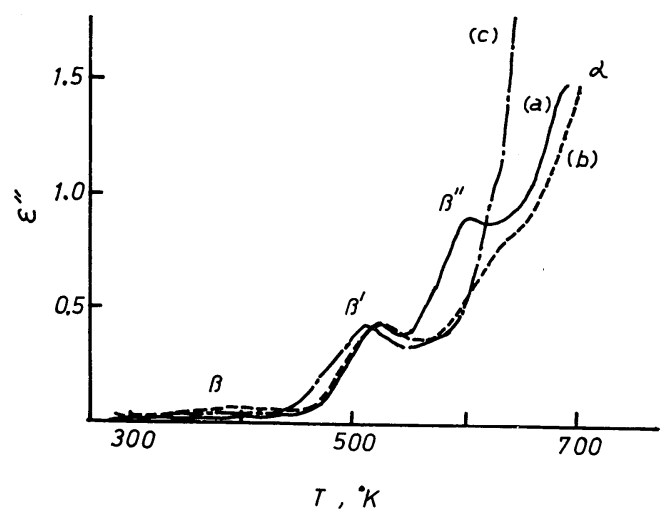

Fig. 2. Dielectric properties of polypyromellitimide $[30 \mathrm{~Hz}]$ a : As received ; b : Annealed at $420^{\circ} \mathrm{K}, \mathrm{c}$ : Coldstretched after annealing at $420^{\circ} \mathrm{K}$.

く小さい. Wrasidlo は同じく $\beta^{\prime} \beta^{\prime \prime}$ を観測したが， $\beta$ はみてい ない. Wrasidlo は乙の温度域で, 示差走査熱量測定 (DSC) を 行ない，此熱の顕著な変化はみられないといっている．われわれ も同様な観測をした。

われわれは冷間延俳試料の熱収縮を熱分析法（TMA）によっ て解析し, 三つの収縮過程を見出した ${ }^{3}$. 試料の長さの温度変化 率が極大值を示す温度は, 力学分散の三つの温度と対応している. TMA によって求めた三つの緩和過程の活性化エネルギーは, そ れぞれ $\beta^{\prime} 10 \mathrm{kcal} / \mathrm{mole}, \beta^{\prime \prime} 25 \mathrm{kcal} / \mathrm{mole}, \alpha 33 \mathrm{kcal} / \mathrm{mole}$ であっ た. Wrasidlo が誘電緩和によって求めた值は, $\beta^{\prime \prime} 25 \mathrm{kcal} / \mathrm{mole}$ $\alpha 43 \mathrm{kcal} /$ mole で, よく一致している.

われわれはまた延伸により密度が三段階に変化することを見出 した . 第一段階で密度はほとんど変らず, 第二, 第三段階で延 伸によって減少する，通常の高分子鎖の塑性変形では, 密度は延 伸によって増加するから, ての変化は塑性変形ではなく, ガラス 状態における分子鎖のコンホメーションの変化により, 自由体積 が増加することを示す.

$2 \cdot 3 \alpha$ 分 散

最も高温の緩和は, 無定形高分子のガラス転移と考えたいとと ろであるが，乙の領域で弾性率があまり低下しない（軟化しない） こと, 此熱の変化がみられないとと, しかも一たん $770^{\circ} \mathrm{K}$ まで 加熱してから冷却すると，乙の転移は再び加熱したとき現われな いことなどから，通常のガラス転移と考えにくい．

Gillham らはてれをガラス転移と解釈し, 加熱中に劣化が起
るので,一たん加熱したものには現われないと考えた。しかしわ れわれは， $\beta^{\prime \prime}, \alpha$ を含むての領域の力学吸収が, 冷間冷伸によっ て極めて大きくなることと, 加熱すると一たん消失するが, 熱処 理した試料をもう一度延伸すると，再び大きい吸収を示すととを 見出した ${ }^{3)}$. 乙の事実は， $\alpha$ が劣化により消失するという Gillham の考えとは一致しない. 何らかの意味で分子鎖の内部回転 によるコンホメーションの変化が $\alpha$ 分散を導くには違いないが, ガラス転移のような分子全体にわたる大きな分子運動は起ってい ないと解釈すべきであろう。しかもそれにつづいて $820^{\circ} \mathrm{K}$ 以上 で真の劣化が始まるので，とのポリマーの $T_{g}$ は観測にかからな いと解秎すべきである。

$2 \cdot 4 \boldsymbol{\beta}^{\prime \prime}$ 分 散

この分散は $\alpha$ よやや下の温度に現われ, 延伸に対しても $\alpha$ 分 散と同様の挙動を示す. しかし, 誘電緩和でも, 密度変化でも, 明らかに $\alpha$ とは別の温度域に現われる. 分子の局部的コンホメー ション変化が， $\alpha$ より若干狭い範囲に起るものと考光られるが, どの部分がどのように対応するかについては, まだ結論をえてい ない.

$2 \cdot 5 \quad \xi^{\prime}$ 分 散

この分散は Butta $ら^{8)}$ が $\beta$ *分散と呼んだもので, 乾燥して も消失せず, 水分散と区別された. しかし Wrasidlo は彼の力 学測定 $(110 \mathrm{~Hz})$ では, $300^{\circ} \mathrm{C}$ 亿乾燥すると $\beta^{\prime}$ がなくなると いっている.逆にわれわれは, 水分を吸収させると， $\beta^{\prime}$ が大きくな るととを観察した。 このととから， $\beta^{\prime}$ 分散が全く水と関係がな いとはいい切れない.

$\beta^{\prime}$ 分散に対応する熱収縮過程の活性化エネルギーが比較的小 さいとと, 密度の変化が生じないとと, 誘電吸收が小さいととな ぞから, ての分散は分子間の結合（特にフェニレン環, 又はイミ ド環の相互作用）の変化に伴う緩和のように考えられるが，確か な証拠はまだない。

最近 Sauer ら ${ }^{9)}$ が主鎖にパラフェニレン環をもつ各種の高分 子が，その力学分散において $\gamma$ 分散 $\left[150^{\circ} \mathrm{K}, 1 \mathrm{~Hz}\right]$ を示すととを 指摘した。 ポリイミドの $\beta^{\prime}$ 分散はてれよりやや高温にあるが, おそらくこれに相当するものと思われる。

\section{文献}

1）加藤貞二, 下村仁, 古屋洋一, 長坂恒治, 横田力男, 神戸博 太郎, 材料 20, 582 (1971).

2）神戸博太郎, 加藤貞二, 空閑重則, 横田力男, 材料 21, 405 (1972).

3) 加藤貞二, 古知政勝, 佐々木哲男, 村上雅茂, 神戸博太郎, 材料22, 472(1973).

4) Lim, T., V. Frosini, Z. Zaleckas, D. Morrow, J.A. Sauer, Polymer Eng. \& Sci., 13, 51 (1973).

5) Roe, J.M., E. Baer, Intern. J. Polymer. Mater., 1, 111 (1972).

6) Gillham, J.K., M.B. Roller, Polymer Eng. \& Sci., 11, 295 (1971).

7) Wrasidlo, W., J. Macromol. Sci.-Phys., B6, 559 (1972).

8) Butta, E., S. de Petris, M. Pasquini, J. Appl. Polymer Sci., 13, 1073 (1969),

9) Chung, C.I., J.A. Sauer, J. Polymer Sci. A-2, 9, 1097 (1971). 